\title{
Four Generations for Generations: A Pow Wow Story to Transform Academic Evaluation Criteria
}

\author{
Kathleen Absolon
}

\begin{abstract}
Within this article, I share a story of four generations of my family and community coming together through pow wow dancing. I present the storying and re-storing of Indigenous scholarly engagement through pow wow regalia making and dance to accomplish two things: 1) to center Indigenous knowledge, kinship and community work through scholarship; and 2) to generate merit and value in the good work in which Indigenous scholars engage. Our creative and cultural selves are often excluded in terms of what receives value and merit in collective agreements. The academy wants us to teach, publish, and engage in community service. My community service is often within Indigenous kinship and community service where I engage in creativity and expressive arts. Evaluations of our tenure attribute value, credit, and merit for work produced, service generated, and research conducted steeped in a eurowestern definition of scholarly work. We theorize about the significance and importance of our culture and traditions; however, our families and communities' practices are regarded as external and outside of the eurowestern academic contexts. This article brings together the knowledge of preparing for and dancing in a pow wow as valued and good work of Indigenous scholars within the academy. It calls attention to a need to revise systems of value and merit in a manner that benefits Indigenous scholars' whole knowledge systems.
\end{abstract}

KeYWords Indigenous knowledge, collective agreements, merit, decolonization, kinship and community, Indigenous scholarship

It's time for beading and other Indigenous women's modes of knowledge production to become a part of the lives of those within the academy (Ray, 2016, p. 376).

I am an Indigenous/Anishinaabe philosopher, knowledge seeker, and community helper. I am a mother, daughter, grandmother who loves kinship and community. I am a bush woman who loves chopping wood, hauling water, being on the land, singing, dancing, sewing, painting, and drumming. And I hold a faculty position in the academy. Many times over the years, I have felt like my whole indigeneity did not fit within the academy primarily because academia "obviates the need for spiritual guidance and inspiration, and it promotes head thinking over heart thinking (Stonechild, 2020, p. 167). Universities have been dismissive of Indigenous worldviews where spirit, heart, knowledge, land, relationships, and ancestors matter. I think that 
Cree scholar Blair Stonechild accurately describes my dissonance in stating that the "university disciplines promote rationality, science, and technology as solutions to contemporary society's challenges" (Stonechild, 2020, p. 168). Within academia, there still does not seem to be any value placed on all parts of who I am that contribute to my role as an Indigenous scholar. Sometimes my ambidextrous consciousness gets weary navigating systems that are foreign to my being (Little Bear, 2000). First, I have to acknowledge the work of my many brothers and sisters across Indigenous nations who have informed my work, such as Dr. Marie Battiste (Mi'kmaq), Dr. Leroy Little Bear (Blackfoot), Dr. Susan Dion (Potwatomi-Lunapé), Dr. Lauri Gilchrist (Cree), Dr. Michael Hart (Cree), Dr. Verna Kirkness (Cree), Herb Nabigon ban (Anishinaabe), Dr. David Newhouse (Onondoga), and Dr. Linda Tuhiwai Smith (Maori) who have all been leaders in Indigenous education in creating space for Indigenous students, curriculum and faculty and whose work continues to inform ongoing transformation. There are so many others, and this article accompanies their work, and for that I am grateful.

Within this article, I share a remarkable story of my family and community with a hope of generating structural shifts within the academy. I want my academic evaluations toward tenure or promotion to include my wholistic Indigenous identity. Often our creative and cultural selves are excluded in terms of what receives value and merit in collective agreements, which is what tenure and promotion committees refer to in deliberating tenure and promotion. The academy wants us to teach, publish, and engage in community service. My community service is often kinship and Indigenous community service, where I engage in restoring ceremony, medicine walks, cultural knowledge through creativity, and expressive arts. My community service extends beyond the academy. If the academy is going to value Indigenous knowledge, they must also value the work/service we do in the places where Indigenous knowledge is cultivated.

The reality is that my Anishinaabe identity, like other Indigenous scholars, within the eurowestern university context is marginally recognized (Absolon \& Dion, 2017; Corbiere, 2019). I receive credit for work done if done within parameters of eurowestern standards. Whole expressions of Indigeneity in culture, language, and creative work are marginally afforded value wherein "performance evaluation criteria utilized by universities inhibit this vital work...Creative writing, such as short stories that would serve pedagogy, is also unlikely to be deemed scholarly work" (Corbiere, 2019, p. 19). I am not saying that our settler peers do not appreciate our cultural presence or the rich Indigenous knowledge bundles we share. The omission of valuing it in our tenure is a structural issue.

Western theoretical hegemony manifests primarily in educational institutions. The most harmful assumptions are that western thought ought to be the standard educational platform, is automatically relevant and valid, and is universally applicable. The Aboriginal person becomes a virtual non-entity in institutions that marginalize Aboriginal thought and reality through the neglect and erroneous authoring of Aboriginal cultural knowledge, languages, and colonial history (Sinclair, 2019, p. 12). 
There seems to be marginal spaces for ourselves as cultural artists and expressive artists in academic collective agreements to recognize and give credit to the core work we do within our kinship and community systems. Evaluations of our tenure attribute value, credit, and merit for work produced, service generated, and research conducted that is steeped in eurowestern definitions and models, and these eurocentric standards create tensions in how we work, partnership, and prioritize (Absolon \& Dion, 2017). We theorize about the significance and importance of our culture and traditions; however, our families and communities practices are regarded as external and outside of the eurowestern academic contexts. When people see me dancing with my regalia, they typically respond with amazement having had no idea that I was a traditional dancer, let alone that I create traditional regalia and craft traditional ceremonial objects. There is so much my peers do not know about me because in the university contexts, the academy values the intellectual and physical realms of our indigeneity and leaves out heart and spirit. Yet, my heart and spirit are with my family and communities and do not leave me when I go to work. This brings me to why I wanted to write this article as an Anishinaabe who is engaged in my community as a traditional dancer and maker of traditional regalia and an intellect and scholar. Valuing whole Indigenous knowledge sets (Absolon, 2019) is the challenge of weaving Indigenous peoples' knowledge into eurowestern academic settings, coined trans-systemic synthesis (Battiste \& Henderson, 2000). This weaving is challenging much like the current day challenges in defending the land, water and Indigenous sovereignty. Colonial violence is ever present in acts of commission and omission.

As I bear witness to the strong-armed and military presence of Royal Canadian Mounted Police (RCMP) and Ontario Provincial Police (OPP) to Indigenous land defenders, I increasingly feel pushed to assert self-determination of my scholarship by weaving layers of subjective knowing, experience, and kinship community into my writing. In the academy, faculty are prescribed colonial standards that we are expected to subscribe to, but which we have not had input into and which we are evaluated against. Standards that omit where Indigenous peoples' priorities typically rest in restoring and protecting Indigenous knowledge, language, and traditions. Indigenous scholars face challenges being underrepresented within the academy, including institutional racism, cultural, and community disruptions (Judge, 2018). Indigenous scholars also are sought out for their Indigenous knowledges and ways of knowing, cultural experiences, and community relationships and are recruited into Indigenous postings. Still, we have to leave our communities and cultural contexts to do so. Institutional racism is evident through omission when Indigenous scholars are underrepresented on promotion committees and when the criteria for promotion is steeped in models of scholarship based on western disciplinary knowledge systems and omit Indigenous models of knowledge. Indigenous scholars end up engaging in work that has little benefit to our kinship and communities, or the work we do does not receive credit, value, or merit within academia (Corbiere, 2019). By problematizing issues of underrepresentation and value, like other Indigenous scholars, we are generating knowledge and "developing new syntheses and methodologies to decolonize [ourselves], [our] communities, and [our] institutions, as well as bring about a blended transsystemic synthesis in an educational context" (Battiste \& Henderson, 2009, p. 5). The layers 
of colonialism, decolonialism, and Indigenization in colonial academic environments are all around us and "universities had not been thinking about Indigenous people when they were moving forward with their governance structures and plans" (Talaga \& McMurchy, 2019, p. 6). The contradictions and rhetoric have never been more apparent than it currently is with the Wet'suwet'en blockades and protests across Canada and the United States. We have been here before, again and again, as colonial control agents use military force to take over Indigenous lands and territories. At all levels, academia and specifically colonial evaluation criteria within the academy omit placing value on the good work Indigenous scholars carry out in restoring Indigenous knowledge within kinship and community systems.

Like other Indigenous authors, I push back by centering and storying my lived experiences, Anishinaabe knowledge and community toward restoring the good life of lived Indigenous knowledge systems (Settee, 2013). This push back is to counter the marginalized place Indigenous women's knowledge traditions have within the academy. When we bring our whole selves into our teaching, research, and service, our whole presence contributes to "unmarginalization" (Ray, 2016). I seek to realign my Anishinaabe-kweness (Anishinaabe womanhood) in my writing and integrate a personal kinship story of family and community (referred to as The Grand Entry). My wholistic knowledge bundle matters (Absolon, 2019). My four generations story is the main pillar that upholds my article. I integrate Indigenous scholarship to support the Indigenous knowledge rooted in pow wow regalia making and dance. Regalia making, beading, threading, and stitching is knowledge and community service that is indeed worthy of merit because this "good work does not just come from the mind, but from the heart as well. It must include physical, intellectual, spiritual, and emotional dimensions" (Ray, 2016, p. 373). The wholistic community and kinship work in preparing for a pow wow, round dance, community feast, language class, shawl making, and beading are all examples of the good work Indigenous scholars engage with while restoring Indigenous knowledge traditions from their academic positions. This article tells a story of restoring kinship of four generations of dancers within a beautiful gathering that celebrates Mother Earth and life (the pow wow). Further to this story is an engagement with how my good work relates to what we carry and care for as Indigenous scholars in the academy and where structural shifts are required to generate transsystemic synthesis for Indigenous scholars. As many stories go, I am the storytelling and weaver of my Indigenous identity into my position within the academy on a search for transsystemic synthesis.

\section{Four Generations: A Grand Entry}

Together, a community and family gathered to sew, bead, make moccasins, dance, and sing a young woman who is lifted up as head dancer. I begin with a story of a visual and oral expression of a spiritual, social, intellectual and cultural heritage that is deeply seeded in our ancestors' presence and relationships to the land and Creation. Storytelling and co-creating are Indigenous forms of knowledge creation. I present the storying and re-storing of Indigenous scholarly engagement through pow wow regalia making and dance to accomplish two things: 1) to center Indigenous knowledge, kinship, and community work through scholarship; and 2) 
to generate merit and value in the good work in which Indigenous scholars engage. The place of this article is the pow wow arena. The pow wow dance is an expression of strong deep-seeded heritage connecting Indigenous peoples to Mother Earth and all our relatives in Creation. Once outlawed under colonial rule, these gatherings are now active acts of reclaiming and recreating Indigenous knowledge and traditions through ceremonial land-based celebrations and community relationships. These gatherings are sources of knowledge. I am acutely conscious that Indigenous knowledge is searched, accessed, and also created alongside of other people we engage with and through the events we participate in, experience, and learn from. Coming to know in Indigenous education is experiential. I have attended and/or danced pow wow for 25 years. My children danced pow wow. My family attend and are vendors or pow wow dancers.

On September 28, 2019, at the University of Waterloo pow wow, four generations of my family dressed in dancing regalia and entered into the grand entry proudly taking our place in the dance arena. In this line, my mother is first generation, I am second, my children are third, and my granddaughter is fourth generation. This is remarkable evidence of how we, as Anishinaabe women, are restoring identity, knowledge and culture. It is especially significant that we are survivors of Indian residential school policies set out to extinguish and eradicate us. Indigenous peoples are increasingly turning to Indigenous knowledge, cultural traditions, and ceremonies to build leadership capacity and restore relationships (Cote-Meek et al., 2012; Manitowabi \& Gautheir-Frohlick, 2012).

In my family and community, I am an Anishinaabe helper, knowledge keeper, sewer, artist, community member, and scholar, enacting Indigenous knowledge systems by sewing traditional regalia, bringing family together, building community and lifting up my daughter as a young head dancer. As an Anishinaabe scholar, I am actively engaged in healing from the violent and traumatic impacts the Indian residential school system left in my family by restoring traditions and kinship systems through all the regalia-making layers. To sew regalia is Indigenous knowledge keeping. The restoration is real, lived and remarkable given the violent history of extermination and genocide policies we are now surviving.

The story of making and preparing fancy shawl regalia for my daughter and niece includes several layers of kinship. It involves my skills as a seamstress; working together as a family; beadwork made by kinship sisters; moccasins made by Cocomish; hair by another sister; invitations come from community; and community circles the dancer. All this work allows for four generations to arrive at the pow wow. Knowledge creation and knowledge sharing happen before, after and during the pow wow.

When I entered the eurowestern academy, I was Anishinaabe and still am Anishinaabe. I do not believe that my non-Indigenous academic peers understood fully what my presence meant in terms of institutional change in community relationships, collective agreements, smudging in buildings, ceremony, circle work, and Indigenous research ensue as a result. Before I am a scholar, I am Anishinaabe kwe, a Flying Post First Nation member, Treaty 9 of the Nishnawbe Aski Nation. I am in recovery from the history of colonial trauma to my family through the Indian residential school system. I am decolonizing my mind by unpacking the presence of dominant eurocentric ideologies, theories, and methodologies. My Indigeneity gets restored through 
wholistic practices that include attending to my spirit, heart, mind, and body as an Anishinaabe kwe (Absolon, 2019). I am a craftsperson who restores traditional items and clothing.

I sew traditional regalia and ribbon skirts, ribbon shirts, bundle bags, bundle cloths, and make things we use in our ceremonies. I feel most proud to be a sewer in creating regalia and ribbon outfits for my family and community members. Anishinaabe scholar Marianne Corbiere wrote about her work as a language carrier and faculty member. She stated that in her language revitalization work, all of her work is not regarded in merit or promotion applications (Corbeire, 2019). We share a commonality here. The knowledge of crafting traditional regalia is tied to years of teachings and knowledge that has existed and been passed from one generation to the next. My mother taught me to sew and the women in my communities, together, passed on other knowledge related to regalia making. I see my knowledge of sewing and creating regalia deeply connected to knowledge transmission within Indigenous kinship knowledge systems.

This remarkable story of restoration and inclusion began with an invitation (Absolon, 2016). In 2019 my daughter was invited to be lead female dancer at the University of Waterloo pow wow, where she had completed her undergraduate degree. The Indigenous Student Centre (ISC) staff invited her to be the head female dancer and she was both nervous and excited. When she told me of the invitation, I was delighted, and by offering to help make her regalia with her, I took up teaching and learning responsibilities. In academic terms, one might say I agreed to be her supervisor. I was delighted because my daughter had put dancing aside when she was a teenager and now, in her mid-twenties, she was on the cusp of returning to the pow wow arena. In June, I started the regalia making process on one condition - that she would help in the process. My niece also wanted to join in and have regalia made (she too had put dancing aside during her teenage years). In support of her desire to restore dancing into her life, I offered to do her regalia as well. Both outfits would be fancy shawl dancing regalia. Without delving into the intricacies of regalia making, the moments of coming together as a family were profound moments of restoring family relationships. My daughter, niece, sister, and I spent time together working on the fancy shawl ribbon fringe. The process of designing patterns, colors, and placement of ribbons is intricate and time consuming. As we worked on it, we talked about life, laughed and bonded while putting all the love of our relationships into the fancy shawl ribbon fringe. I watched my daughter and niece work together and support each other as they dealt with ribbon placement details one by one. They planned ribbon color placements and talked about their return to dancing journeys. Knowledge and understanding were created; patience, determination, support, love, kindness, and spirit were interwoven into the ribbons making their shawls dance like butterflies. The fancy shawl dancers emulate beautiful butterflies.

Closer to the pow wow date, other women from the community began the beading of hair ties, earrings, headpieces, barrettes, and neck pieces. My mother began making moccasins to wear with their regalia. The young women talked to Cocomish (grandmother) about their regalia colors and bead color choices. Restoring connections and relationships to Indigenous traditions and teachings in life happened throughout the layers of preparing for the pow wow. Engagement in kinship community learning is where leadership building begins. Through the 
use of cultural and creative-based processes, youth learn that they are supported, prepared, and ready to become leaders (Cote-Meek et al., 2012).

In my life, lived Indigenous scholarship unfolds from my Anishinaabe culture steeped in ancestral knowledge and oral traditions. This is where kinship systems and community build leaders, pass on knowledge, and provide a lived educational arena for our people. In publications, we begin with a blank page and build from there, drawing on our peers and scholarly communities' genealogies of knowledge. In these moments, the material is my blank page; the story is in the applique; the knowledge mobilization occurs in passing on teachings, sharing knowledge throughout the process, and at the pow wow through dance and enacting centuries of oral traditions. My Indigenous scholarship began with a vision of regalia and shawls, and like a manuscript, it took months to create. I have included a photographic compilation of how living Indigenous knowledge comes from within and moves into kinship and community.

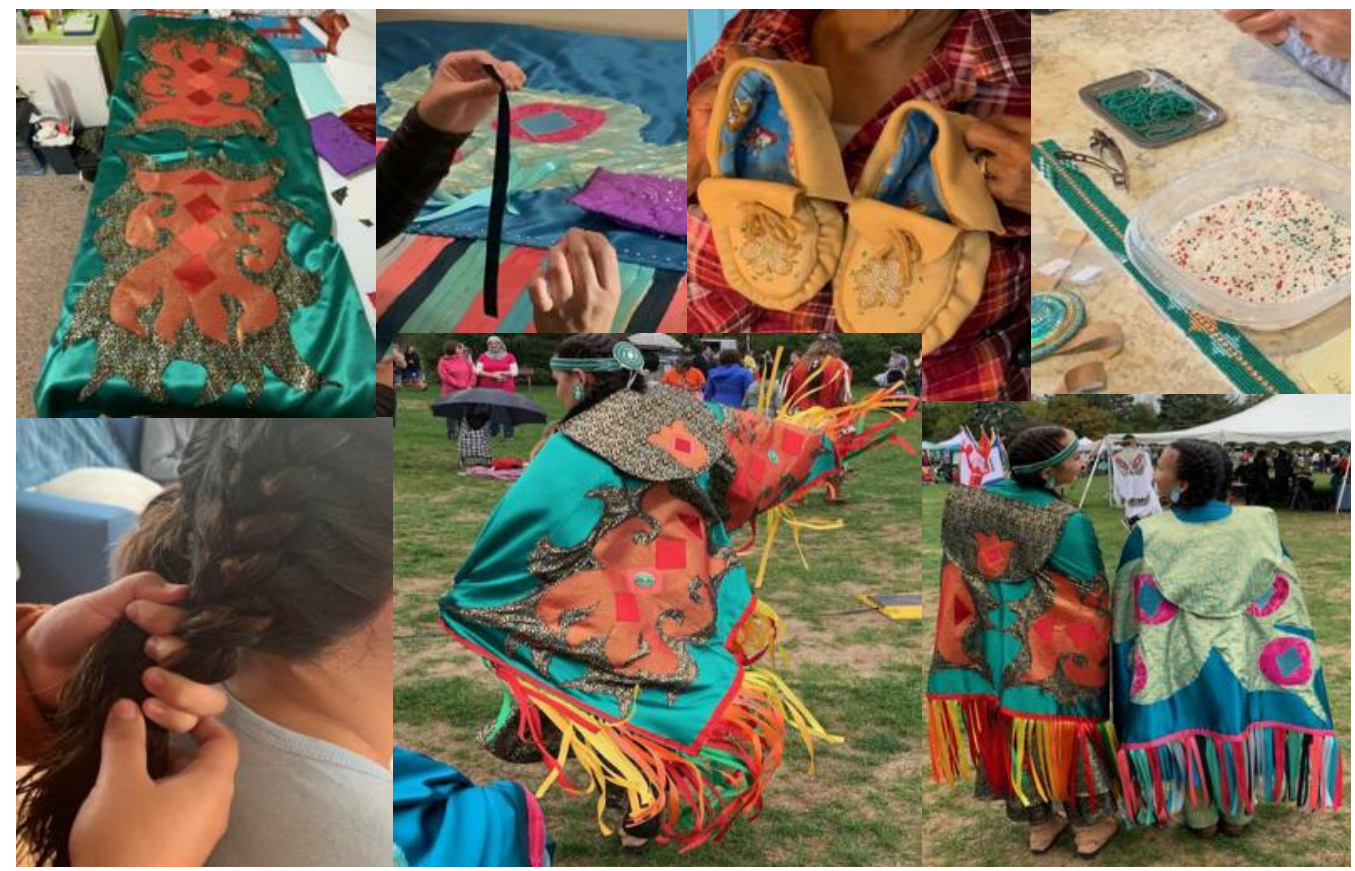

Figure 1. The works of preparing and participating in the pow wow dance.

Photo credit: Kathleen Absolon.

The collage of photos here provides a visual representation of the knowledge mobilization journey. It is from top left to top right: the shawl was visioned and created from a textile. Over months it was developed, drawing on oral traditions and knowledge; restoring kinship and family relationships happens with co-creation of the shawl. The next photo is of ribbons being placed one at a time by the two young dancers. The third photo to the right is the moccasins made by the dancers' Cocomish (Grandmother). The far top right photo is the beading an auntie is creating and, again, more knowl edge is created and passed on. The lower left photo is of a younger sister braiding the head dancers' hair and relationships of interdependence are 
fostered and restored. The central and far-right photos are of the knowledge mobilization of the dance. The dancers take their leadership roles in the community as rich cultural traditions and knowledge are restored among kinship systems and community. I, as supervisor, witness and support this transition of youth into their leadership roles. The process depicted is rich lived Indigenous scholarship steeped in oral traditions, storytelling, kinship, and community. Indigenous scholars are engaged in our community and kinship systems external to university communities. Indigenous kinship and community engagement are often not considered for merit and marginalized in the academy. I think the omission of our good work needs to change.

Through the process of creating regalia, passing on teachings, restoring community, and promoting kinship oral traditions, Indigenous educational processes are enacted that are for many of us more meaningful than writing papers in the academy. On the day of the pow wow, women

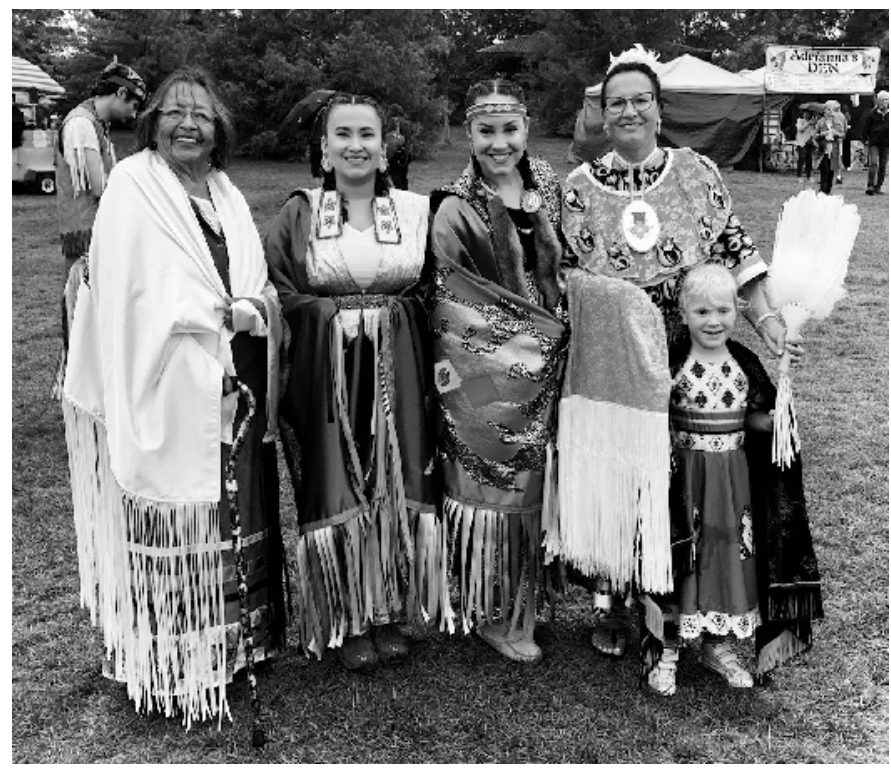

Figure 2. From left to right: Jennie Absolon (my mother), Jessica Varga (my niece), Aki Absolon (my daughter), myself, and my granddaughter Manidoo N'gig. from the community came to our home to prepare the young female head dancer. A younger sister helped braid her hair, and as we all prepared, we feasted, smudged, and shared stories of our lives and dancing moves. Laughter filled our hearts and spirits throughout our work together in preparing for the pow wow. Restoring family and kinship relations was evident at these moments while simultaneously feeling grief about the beautiful and wholistic ways of life our families had before colonial violence attacked our families and children. This is Indigenous higher education!

At the Grand entry, a remarkable coming together of four generations happened. It was a special time that evidenced the disruption of colonialism, its impacts and restoring of relationships, Indigenous identities, and community. Four generations of dancers in my family emerged. I have not experienced this in my life and living it out was remarkable. The matriarch, my mother, who was 87 at the time, was wearing her traditional cloth regalia. Next in line is me, wearing my traditional cloth regalia. The third generation was my daughter, who was head dancer in her fancy shawl regalia, as well as my niece who was in her fancy shawl regalia. The fourth generation, my granddaughter and my mother's great-granddaughter, was wearing her dancing regalia (all made by me). Four generations of familial women spanning a lifetime from spring to winter danced into the grand entry. It was a remarkable moment, an emotional time to experience and beautiful sight to witness. 
Regalia-making and creating required months of good work combined with many conversations about its meaning and co-creation of design with the dancers. Much like my written scholarship, the regalia was shared and steeped in generations of knowledge. Beautiful beadwork, moccasins, shawls and hairpieces were all crafted within a kinship system in relationship with one another. My heart and spirit filled with emotions of joy and grief at the Grand Entry: joy at this moment in time I experienced intergenerational pride, and anger and grief because the transmission of knowledge over generations was assaulted and colonial forces violated our kinships systems. The losses are immeasurable. And within academia, the knowledge and knowledge production evidenced in months of good work is invisible and not credited within eurowestern standards of merit. How different life would have been had we had the consistent generational teachings, love, and support of our grandmothers and mothers. Layers of emotions and thoughts emerged from within. I let my tears flow as I danced, slowly processing all the layers of colonial violence, family dismemberment, family love, kinship and community support, and Indigenous knowledge as we entered into the dance arena at grand entry dancing in unity. I danced with my mother and niece while my daughter led the grand entry. Like a butterfly, my granddaughter gleefully danced in and out of all of us, being protected in the safety of the heartbeat, songs and dancers. Photographers were taking pictures of us because this was remarkable to experience and witness.

Four generations' presence is remarkable because for generations, the colonial government has done everything in its power to rid us of our Indigenous identity, cultural traditions and relationships (to each other, the land, spirit and Creation). We have endured cultural genocide tactics for generations, and today there was four generations of visible resilient Anishinaabe pride in the dance arena.

\section{How is this relevant to the academy?}

My work and the work of other Indigenous scholars who prepare and participate in cultural practices, including pow wow, are not separate from who we are as Indigenous scholars. I would like to receive merit toward promotion to full professor for this work that includes knowledge creation and knowledge sharing. My lived Indigenous knowledge in community attributes value and ought to be included in evaluation criteria. Ultimately, restoring relationships, expertise, and community connections within Creation is where the heart of my work exists. The layers of knowledge, relationships, kinship systems, traditional knowledge, skills, and arts are interconnected into who we are and what we bring into our roles as Indigenous people within the academy.

\section{Generating trans-systematic synthesis: The Heartbeat of being Indigenous and being Indigenous in the academy}

Generally, Indigenous scholars carry a unique and distinct knowledge system when entering into the academy to restore Indigenous practices and knowledge in spaces of education, research, and learning. We also bring our community relationships and responsibilities. Sustainability of knowledge, community connections, relationships and relational accountability continues 
because of our community connections, relationships, cultural identity, nationhood, and vision to restore, reclaim and recover our knowledge and traditions (Absolon \& Dion, 2017; Battiste, 2002; Battiste \& Barman, 1995; Cote-Meek, 2014). We teach about who we are. We live this location out in our daily lives as Indigenous peoples. How we sustain ourselves is embedded in our rich cultural traditions, way of life on the land, and relationships within our community and kinship structures. The physical well-being of pow wow dancing, singing, and drumming through community gatherings regenerates health, community relationships, and Indigenous knowledge (Manitowabi \& Gautheir-Frohlick, 2012; McGuire-Adams, 2017). Indigenous identity, nationhood, and knowledge are increasingly asserted within higher education. This self-determination for the "recognition and intellectual activation of IK today is a growing, purposeful, and political act of empowerment by Indigenous peoples" (Battiste \& Henderson, 2009 , p. 5). Indigenous faculty retention within the academy, for me, is about how I am able to sustain my identity and nationhood within my faculty role and responsibilities and how I support Indigeneity at the center of my teaching, research, and community service. The how is the heartbeat of being Indigenous and being Indigenous in the academy and how we "activate holistic paradigms of Indigenous knowledge to reveal the wealth and richness of Indigenous languages, world views, teachings, and experiences, all of which have been systematically excluded from history, from contemporary educational institutions, and from Eurocentric knowledge (EK) systems" (Battiste \& Henderson, 2009, p. 5). My passion as an Indigenous scholar is exemplified in that quote.

Indigenous knowledge systems transmit knowing that life is a gift from Creator and human life is sustained by Creation (water, land, all four legged, winged, crawling and swimming creatures, plants, and trees). Wholistic knowledge sets are foundational to teaching and learning (Absolon, 2019; Battiste \& Henderson, 2009). Mother Earth sustains the heartbeat of life. Hand drums, water drums and big drums emulate this heartbeat of life, and this heartbeat is medicine for the people. When a community comes together to lift the young people to take their place as leaders and head dancers, singers, and drummers, the layers of required knowledge is rooted in generations of traditions within the diversity of Indigenous nations (Cote-Meek et al., 2012; Goudreau et al., 2008; Victor et al., 2016). The heartbeat of being Indigenous in the academy cannot be separate from this heartbeat of life. When I first heard the drums, my heart skipped a beat, and I knew I was home and that I belonged. Searching for one's heartbeat through the drum is a search for life, wellness, and identity (Goudreau et al., 2008; Laurili, 2016; Pedri-Spade, 2016). Cultural gatherings such as the pow wow tradition celebrate and honor the heartbeat of life (through the ceremonies \& big drums). All aspects of the pow wow dancers and attendees emulate the layers of Creation and community. Increasingly there is evidence that culturally-based practices support and restore cultural identity, leadership development, healing, and community relations (Archibald \& Dewar, 2010; Cote-Meek et al., 2012; Flicker et al., 2014; Geia et al., 2013; Manitowabi, 2012). 


\section{The Four R's: Principles for Change}

I echo what many Indigenous scholars have voiced. It's time to rethink, revolutionize and decolonize the way the academy treats Indigenous scholars. It's time to generate concrete shifts that benefit the workload recognition of Indigenous scholars whose heart and spirit work is underrepresented in their evaluation criteria. Academic spaces require a reconfiguration toward inclusion of Indigenous knowledge, transforming academic standards and value knowledge from other ways of knowing with a "reduced reliance on European knowledge" (Drumbrill \& Green, 2008, p. 497). The following principles are guidelines toward crediting Indigenous knowledge holders living out their knowledge within their kinship and community systems. I propose an adaptation of the four Rs in education to move academic policies to support the Indigenous people who bring their Indigenous knowledge bundles to the academy. The four R's originated with esteemed Elder Verna J. Kirkness (2013) to transform teachers in Indigenous education. Respect, relevance, reciprocity, and responsibility come to my mind when I consider what guidelines and protocols emerge from this remarkable story and the significance of this story to Indigenous faculty and teachers in the academy. These principles are also important in navigating the complex community-university partnerships we engage in (Absolon \& Dion, 2017). Who we wholistically are, as Indigenous peoples, matters because core parts of Indigenous faculty are erased and unvalued through tenure and promotion guidelines typically referred to as the holy trinity of academia: teaching, research, and university service. Our spirits, language, culture, land, ancestors, art, skills, history, lived experiences, and knowledge form our whole selves and are core facets of Indigenous identity that we carry and where our contributions to teaching and research are rooted. Ironically, I have to make this visible by writing about it in a scholarly journal for publication. Currently, there is no space to value this contribution in my promotion or tenure application. I am sure this is a common experience across the academy. My goal is to make our whole selves visible and eligible for merit and to push the academy through my four generations story and through relating it to the four Rs.

The first $\mathrm{R}$ represents Respect. Respect means becoming familiar and enacting existing policy documents and statements that call for valuing Indigenous scholars' existing relationships to their good work undertaken in their kinship community learning and teaching environments. I can name six existing documents with recommendations that promote respecting Indigenous cultural heritage, traditions, languages, communities etc., beginning with the Constitution of Canada where Section 35(1) affirms existing aboriginal and treaty rights above all others (Battiste \& Henderson, 2000). Understand the 1996 Royal Commission on Aboriginal Peoples, with its plethora of recommendations to shift relationships (Erasmus \&Dussault, 1996). Enact for the Calls to Action (specifically 62-65) in the Truth and Reconciliation report (Truth and Reconciliation Canada, 2015). Understand that, in 2015, Universities Canada asserted principles on Indigenous Education that recognize Indigenous communities' autonomy and self-determination and that support Indigenous students, faculty, and staff in providing leadership to respond to Indigenous peoples' and communities' educational needs (Universities Canada, 2015). Get to know the Canadian University Association of Teachers (CAUT) Indigenizing the Academy policy statement of 2016, a statement to promote practices that support Indigenous faculty and staff. Fifthly, 
understand that The United Nations Declaration on the Rights of Indigenous peoples asserts Indigenous peoples' cultural and heritage rights (United Nations, 2007). The Indigenizing the Academy statement is explicit in its call to revisit collective agreements for Indigenous faculty and staff. For example, I have extracted a couple of points to highlight policy and practices for:

Explicit recognition, in all Aboriginal academic staff hiring, training, and evaluation procedures, of special qualifications and contributions including: development and sharing of Indigenous knowledge and languages; engagement with culturally appropriate research and publication venues; community service; and any other relevant considerations, including lived experiences within Aboriginal communities. Explicit recognition of, and appropriate compensation for, any increased workload that may be taken on by Aboriginal academic staff as a consequence of their community status and/or obligations.

Appropriate opportunities and support for Aboriginal academic staff to ensure the maintenance of significant ongoing relationships with their home communities, lands and waters. (Canadian University Association of Teachers [CAUT], 2016)

Respect for Indigenous faculty's cultural knowledge, traditions, values, and activities that they bring us into our teaching and faculty work. Respect means to credit community responsibilities: When Indigenous people enter into eurowestern academic spaces, it's highly likely they are only receiving credit for their intellectual scholarship. The forms of evaluation criteria are built on models of education steeped in colonial ideologies upholding eurocentric hegemony. The evidence in policy statements, recommendations and strategic plans for academia to enact respect for all the facets of who Indigenous people are and credit the Indigenous knowledge scholars engage in from within the academia and within Indigenous kinship and community systems.

Indigenous scholars have shifted Indigenous research paradigms and have made some significant inroads in knowledge production forms in the academy (Absolon, 2011; Kovach, 2009; McGregor et al., 2018). Increasingly, there is evidence of wholistic methodologies in research being valued in SSHRC grants, Ph.D. theses, and academic research strategies. The proof of bringing Indigenous arts-based knowledge into research is becoming more visible, and Indigenous methods of knowledge translation are being recognized and valued. I offer several examples here to demonstrate how storytelling, teaching, sewing, arts, and supporting youth leadership are valued methods in kinship and community-based research projects. In a shawlmaking project, Jackson et al. (2015) assert that "shawl making and storytelling are processes of knowledge creation connecting participants with Blackfoot culture by foregrounding ceremony, the importance of Elders, and role modeling Blackfoot values" (p. 12). Lynore Geia and others (2013) also bring into their research methods yarning (aka storytelling), like Indigenous peoples across the globe rely on yarning/storytelling as an "ancient practice used by Indigenous persons/cultures for thousands of years that is integral to Indigenous learning within different spheres of life (p. 14). Flicker et al., (2014) engage Indigenous youth in their 
communities with arts-based methods shifting both methodologies fueling Indigenous art, creativity, and building kinships. A step in the right direction is the emergence of Indigenous arts, skills, and knowledge embedded in Indigenous community-based practices under university - community collaboration projects (Fraser \& Voyageur, 2016). These projects are leading the way to recognition of Indigenous research methodologies. Transferring the value of Indigenous knowledge in research is productive, yet more inroads are necessary to revisit evaluation criteria in collective agreements.

Further to the inroads we are achieving in Indigenous research, shifting what receives merit and value in the academy requires respect for the lived knowledge, stories and methods of teaching, research and, service Indigenous people carry. When faculty publish their wonderful research projects, the publication is counted, and I witnessed the counting of publications in promotion committee meetings. Respect means to take a second look, to re-speculate, which in the academy translates to crediting and valuing all the good work and time Indigenous faculty are hired for and carry out in relationship building, sharing Indigenous teachings, language, and in restoring kinship and community systems. There is real merit in restoring regalia making, restoring four generations, and restoring Indigenous knowledge within the pow wow arena in tenure and promotion community service categories for Indigenous scholars. The absence of valuing these contributions lends to the dual knowledge bundles Indigenous scholars carry, with academic value placed only on one.

The second R represents Relevance. Indigenous faculty need to feel their whole life has relevance to their work in the academy, where respect is embedded in their curricula, research, and community service. Who is your community and where does your community service reside? Community service within their Indigenous communities and kinship structures ought to be factored into promotion and tenure. Relevance means promoting a teaching, research, and community portfolio that is relevant to Indigenous faculty priorities. This eventually fosters the retention of Indigenous faculty. Priorities for Indigenous faculty tend not to align within the merit ascribed by collective agreements that push faculty to publish or perish. Indigenous people will leave academic posts because the pulling apart of oneself is too harmful. Often Indigenous faculty have fewer publication records because we are oversubscribed across the university (internally and externally). Our priorities are in restoring language, cultural traditions, knowledge, and in doing Indigenous community service. Lana Ray, An Anishinaabe scholar, integrates beading into her research, and it is in the research arena and publications where change is happening in recognition of Indigenous research methods. She beads and restores this traditional skill into a research methodology employing beading and articulates the interdependent relationship between beading as an art and knowledge translation:

Beading's intrinsic relationship with storytelling, process, and aesthetic activates the fields of collective consciousness, wholistic knowing, and Anishinaabe ethical principles, providing an outlet to collect, understand, and convey knowledges in a way that is meaningful and relevant within Anishinaabe worldview and aligned with concepts of sovereignty and community wellness. (Ray, 2016, p. 376) 
Beading, sewing, regalia making, and drum making (a few relevant examples) require vision, synthesis, analysis, perseverance, integration, layers of knowledge, and spirit. These are all Indigenous means of knowledge transmission, translation, and production. This is Indigenous education. A research project, book or article is very similar to generating the knowledge produced in beadwork, regalia, songs, drumming, basket weaving, and the list goes on. The fabric is the blank page, and from there, the knowledge is woven, crafted, and generated. It is how the work of preparing for a pow wow, working with textiles, and restoring family members into the pow wow community gathering is in alignment with gathering knowledge for publication in print and text for the academic community. Ironically, our academies are quick to take credit for hosting such events but omit this work in our promotion and tenure applications.

The third R represents Reciprocity. Indigenous scholars have relational accountability and service responsibilities to our communities from where we come and research. Reciprocity means both relational accountability and collective responsibility to which an individual's merits and honors are accorded. Reciprocity is restoring value and merit for the personal and collective knowledge, relationships, skills, and experiences Indigenous scholars carry into their academic roles. Reciprocity is generating equivalence of knowledge value. Indigenous faculty can receive merit and credit for the oral traditions, cultural knowledge, and living libraries they carry for the collective versus a hierarchal top-down relationship of fitting into eurowestern academic standards of tenure and promotion. While it is a personal gain for Indigenous peoples, it is also a collective gain for the academy. Indigenous scholars' philosophies, knowledge, experiences, and wisdom are steeped in their lived experiences, community relationships, ancestral knowing, ceremonial knowing, nation relationships, and land-based knowledge. Indigenous knowledge holders carry knowledge bundles rooted in Creation's four directions and embed spirit, heart, mind, and body. Creating and transforming spaces allows Indigenous people to be who we are to sing, dance, sew, pray, have ceremony, gather, restore community, restore relationships, restore Indigenous ways of knowing, being, and doing. Often the academy lacks space and relevance to retain and sustain Indigenous knowledge carriers whose sustainability requires land, water, ceremony, and community to thrive. Development for Indigenous scholars moves beyond academic conferences to being with spirit in ceremony, being with Indigenous relatives in community, being with Elders and knowledge carriers, and being on the land with Creation. The pow wow is much more than a cultural tourist event; it is a celebration of life that honors Creation's heartbeat and emulates Creation in the dances and songs. Community is nurtured and sustained through this important gathering. Contributing to restoring Indigenous knowledge and building community is valid community service at knowledge production levels, transmission and mobilization.

Much like generating a written publication, Indigenous creative arts-based knowledge is a process weaving together representations of land, family and community stories that together comprise knowing, being, and doing. Regalia making, beading, singing, dancing, family, and community and their relevance to eurocentric university contexts matters to our work in the academy. A shawl is equivalent to a research paper and carries as much weight and value 
in both knowledge and process (Jackson et al., 2015). A blank canvas or fabric is akin to a blank page that calls for reflection, research, knowledge, meaning, application, and knowledge sharing. There are few university contexts where this knowledge lives and receives visible merit in an Indigenous faculty member's promotion letter. Today, many universities hold space for pow wows, often sponsored and funded by their Indigenous student services or initiatives. However, the knowledge contained within the layers of pow wow traditions is often invisible and unrecognized. Authentically restoring Indigenous knowledge means creating, generating, doing, and being. Indigenous languages are verb-dominated languages implying that Indigenous knowledge is first lived knowledge, based on experiences that become intellectual knowing. They are interdependent forms of knowing. Restoring Indigenous knowledge means teaching students how to sew, how to bead, how to trust that embedded in these practices are life-affirming knowledge and practices.

The fourth $\mathrm{R}$ is for Responsibility. Responsibility to enact the existing plethora of Royal Commission on Aboriginal Peoples recommendations, Truth and Reconciliation Calls to Actions, universities policy statements, university teachers principles, and other documents that support Indigenous faculty, their knowledge, community, and responsibilities while serving higher education. Those engaged in generating trans-systemic synthesis are responsible for shifting disturbers to promote shifts in collective agreements and evaluation criteria that genuinely reflect respect, relevance, and reciprocity of Indigenous faculty. This protocol shifts responsibility for changing institutional standards of value and merit onto the institution instead of Indigenous faculty who are recolonized with eurowestern standards of value and merit. Currently, Indigenous scholars do double duty in fulfilling the eurowestern standards of evaluation, usually in research, publications, teaching, and university committee work; and the second duty in their communities fulfilling existing responsibilities embedded in their roles as knowledge carriers and community leaders. This double-duty leads to double workloads and expectations without fully recognizing the double bind Indigenous faculty are navigating. The next step would be placing value and merit on the good work Indigenous faculty do within their communities and kinship systems. Ironically and typically, it is this knowledge that universities seek and in which Indigenous scholars are grounded. Issues of inequity and disadvantaged playing fields are the academic stakeholders' responsibility, not the already disadvantaged faculty who are over-subscribed within their departments and across the university (Van Katwyk \& Case, 2016). University faculty associations provincially and nationally have the responsibility to revisit these issues and reframe what receives values in Indigenous faculty workloads.

In my years of being involved in academia (since 1992), I have participated in Indigenous academic forums, hosted by CAUT, where Indigenous faculty gather to share experiences, offer support, and express concerns. At these forums, I hear Indigenous academic faculty concerns related to tenure and promotion criteria that omit placing value and merit on priorities Indigenous faculty have in relation to their own communities and kinship responsibilities. Many experiences, issues, and concerns typically echoed among Indigenous faculty across disciplines and the country, but tenure and promotion criteria are prominent. Having been 
involved in national Indigenous university teachers' forums to discuss under-representation issues, institutional racism, working outside of our communities, academic pressures and stressors, and shared learning curves have been sources of great relief, knowing I wasn't alone in these experiences. In an era of Truth and Reconciliation in the academy, it is time to certainly tackle Indigenous faculty evaluation criteria in tenure and promotion. While initially written for teachers in Indigenous education, these four principles help refocus principles for a lens on how to attribute actual value and merit within the academy in a manner that supports the whole package of what Indigenous scholars bring to their academic work and their community work. They should not be separate, and while I am an Indigenous scholar, I am also a member of the community and engage in community and kinship work. I have not been able to bring my kinship work of being a regalia maker, community craftswoman and dancer into the academic arena. My tenure and promotion dossiers do not see my whole self. I am forced to fragment and colonize my presence in the academy. Indigenous scholars' knowledge within the academy is much deeper and richer than many of our settler academic peers (who are often at the helms of evaluating our dossiers for promotion and tenure) may realize. Ironically, Indigenization strategies seek to hire Indigenous faculty and staff who have Indigenous knowledge, connection and relationship to the community while not respecting these hiring requirements in the tenure and promotion process. Perhaps some of these guidelines will find pathways to support Indigenous knowledge holders within the academy and disrupt the generations that education has participated in enacting legacies of colonial genocide, violence and assimilation.

\section{The Dance Out}

When Indigenous knowledge, language, cultural traditions, worldviews, and land-based traditions are wholistically incorporated into our evaluations for merit everyone benefits. The dance out concludes the pow wow, and all dancers dance out of the arena accompanied by the heartbeat of the big drums. As we weave out of the dance arena, I reflect on how I weave who I am and all the good work I do into my work in the academy. I continue to question how we can make all this good work relevant in my academic life. It still seems fractured, and I continue to do double duty with my dual knowledge bundles and dual responsibilities. The dance layers mirror the layers we weave through in determining a pathway toward a good life mino bimaadsiwin. Finally, also during the dance out, I reflected on this day, and how remarkable it was. The day was memorable for many reasons that disrupt the colonial violence of family dismemberment as we came together to dance and celebrate Mother Earth and life. I am aware that our families and communities have been divided and dismembered over the generations from the Indian residential school projects and federal policies created to fragment and divide us. My mother's physical vessel is reaching its end, and if she dances again, it will be a gift to all of us. The coming together of four generations was truly special and unique. In our family, four generations of dancers may only happen once in a blue moon until my grandchild have children, and perhaps I'll be fortunate enough to dance with them in the winter of my years. 
The dance out is both an individual and collective action to value Indigenous knowledge in the academy. Ultimately, issues of stress, burnout, and underrepresentation will decrease and retention of Indigenous faculty will likely grow. This dance out acknowledges that:

When IK is naturalized in educational programs, the learning spirit is nurtured and animated. Individually and collectively, Aboriginal people are able to decolonize themselves, their communities, and institutions, leading to transformation and change; and everyone benefits. Indeed, naturalizing IK creates potential for Aboriginal and non-Aboriginal learners in trans-systemic ways that EK alone cannot do (Battiste \& Henderson, 2009, p. 13)

Indigenous knowledge holders individually and collectively bring their living libraries and Indigenous intelligence to teaching and learning. Our lived experiences and Indigenous intelligence has a spirit, heart, knowing, and movement. Education benefits from our whole contributions: all educators benefit, and all learners benefit.

Adopting the four Rs as principles into review processes in eurowestern academic structures could transform systems that force Indigenous scholars and students to comply with colonial evaluation criteria (Battiste \& Henderson, 2000). "No foundation exists for saying Indigenous worldviews are inferior ways of knowing. According to Eurocentric reasoning, Indigenous worldviews can only be evaluated according to their ability to Indigenous ends" (Battiste \& Henderson, 2000, p. 89). I believe the policy statements are there and the pathways for transformation in place. The inclusion of this four generational story promotes that Indigenous scholars and knowledge carrier's evaluation for promotion and tenure be carried out inclusively of their community and kinship knowledge, responsibilities, and priorities. These guidelines and principles, when adopted, will begin to recognize Indigenous scholars' whole knowledge bundles. All the work we do for the betterment of our kin and communities is worthy of value and merit in promotion and tenure applications. As we attempt to restore Indigenous identity and knowledge within eurocentric university contexts, the challenges and demands of carrying dual knowledge bundles continue to contribute the stress and burnout. It would be so much more respectful if the good work Indigenous scholars do within their communities to restore language, culture, identity, knowledge, community, and kinship was included in their work in the academy. This would be an academic dance out that demonstrates respect, relevant, reciprocity, and responsibility.

Dancing out with trans-systemic synthesis in mind would be a dance where we can blend our whole selves, when our knowledge sustaining our self-esteem, value and worth as Anishinaabe Indigenous peoples is respected and valued. My Anishinaabe knowledge and selfesteem come not from my academic work, but from my traditional teachings, land-based practices, community work, ceremonies, relationships, skills, arts, and crafts. After surviving the onslaught of colonial erasure and genocide restoring Indigenous ancestral traditions, skills and arts is imperative to thriving as a peoples. As I am finding pathways to bring my knowledge from spirit through ceremony, heart through the community, intellect through consciousness 
education, and body through physical expressions of who I am and what I love. Increasingly, we are witnessing the emergence of Indigenous creative arts and expressive arts of sewing, beading, drum making, drumming, singing, canoeing, walking, fire building, hunting, fishing, and so much more as methods in Indigenous research methodologies and in pedagogies that reach the spirits, hearts, minds, and bodies of Indigenous students. Addressing collective agreements and crediting Indigenous knowledge that builds community, restores relationships, and heals generations of families from policies set up to dismember and disconnect us from the land, our culture, and relations will aid a blending of Indigenous knowledge in academia. Achieving synthesis of my Indigenous self within academia calls upon academia to acknowledge the expertise and good work I do within my kinships and community systems by recognizing them as eligible for credit and merit. This knowledge, after all, contributes to our Indigenous scholarly knowledge bundles within our academic positions. It is our Indigenous knowledge to which Indigenization strategies are turning. It's time to address the double standards and give credit where credit is long overdue.

Miigwech and all my relations.

\section{About the Author}

Kathleeen Absolon is Anishinaabe from Flying Post First Nation, Treaty 9, Nishnawbe Aski Nation. She is an Associate Professor in the Indigenous Field of Study and the Director of the Centre for Indigegogy in the Faculty of Social Work, Wilfrid Laurier University. Email: kabsolon@wlu.ca

\section{References}

Absolon, K. (2019). Indigenous wholistic theory: A knowledge set for practice. First Peoples Child and Family Review, Special Issue celebrating 15 years of wisdom. 14(1), 22-42.

Absolon, K. (2011). Kaandossiwin How we come to know. Fernwood Publishing. Absolon, K. (2016). Wholistic and ethical: Social inclusion with Indigenous Peoples. Cogitatio: The Journal of Social Inclusion, 4(1), 44-56.

Absolon, K. \& Dion, S. (2017). Doing Indigenous community-university research partnerships: A cautionary tale. Engaged Scholar Journal: Community-Engaged Research, Teaching, and Learning, 3 (2), 81-98. 
Archibald, L., \& Dewar, J. (2010). Creative arts, culture, and healing: Building an evidence base 1. A Journal of Aboriginal and Indigenous Community Health, 8(3), 1-25.

Battiste, M. (2002). (Ed.) Reclaiming Indigenous voice and vision. UBC Press.

Battiste, M. \& Henderson, J. Y. (2000). Protecting Indigenous knowledge and heritage: A global challenge. Purich Publishing.

Battiste, M. \& Henderson, J. Y. (2009). Naturalizing Indigenous knowledge in Eurocentric education. Canadian Journal of Native Education, 32(1). 5-18.

Canadian Association of University Teachers [CAUT]. (2016). CAUT. https://www.caut.ca/aboutus/caut-policy/lists/caut-policy-statements/indigenizing-the-academy

Cote-Meek, S., Dokis-Ranney, K., Lavallee, L., \& Wemigwans, D. (2012). Building leadership capacity amongst young Anishinaabe-Kwe through culturally-based activities and creative arts. Native Social Work Journal, 8, 75-89.

Corbiere, M. A. (2019). Protecting Indigenous language rights: Much more than campus signage needed. In Academic Matters. Ontario Confederation of University Faculty Association's Journal of Higher Education. Decolonizing the university in an era of Truth and Reconciliation. Spring, 16-20.

Drumbrill, G. C. \& Green, J. (2008). Indigenous knowledge in the Social Work academy. Social Work Education, 27(5), 489-503.

Erasmus, G., \& Dussault, R. (1996). Report of the Royal Commission on Aboriginal Peoples. Canada Communication Group.

Flicker, S., Danforth, J. Y., Wilson, C., Oliver, V., Larkin, J., Restoule, J., Mitchell, C., Kosmos, E., Jackson, R., \& Prentice, T. (2014).”Because we have really unique art”: Decolonizing research with Indigenous youth using the arts. International Journal of Indigenous Health, 10(1), 16-34.

Fraser, J., \& Voyageur, E. (2016). Crafting culturally safe learning spaces: A story of collaboration between an educational institution and two First Nation communities. Engaged Scholar Journal: Community-Engaged Research, Teaching, and Learning, 2(1), 157-166.

Geia, L. K., Hayes, B., \& Usher, K. (2013). Yarning/Aboriginal storytelling: Towards an understanding of an Indigenous perspective and its implications for research practice. Contemporary Nurse, 46(1), 13-17. https://doi.org/10.5172/conu.2013.46.1.3

Goudreau, G., Weber-Pillwax, C., Cote-Meek, S., Madill, H., \& Wilson, S. (2008). Hand drumming: Health-promoting experiences of Aboriginal women from a northern Ontario urban community. Journal of Aboriginal Health, 4(1), 72-83.

Jackson, E. L., Coleman, J., Strikes With A Gun, G., \& Sweet Grass, D. (2015). Threading, stitching, and storytelling: Using CBPR and Blackfoot knowledge and cultural practices to improve domestic violence services for Indigenous woman. Journal of Indigenous Social Development, $4(1), 1-27$.

Judge, A. (2018). Learning lessons from the impacts of relocating Indigenous scholars for academic appointments. (Unpublished PhD Thesis). University of Western Ontario. London, ON. Electronic Thesis and Dissertation. Repository 5520. http://ir.lib.uwo.ca/etd/5520

Kirkness, V. J. (2013). Creatings Space: My life and work in Indigenous education. University of Manitoba Press.

Kovach, M. (2009). Indigenous methodologies. Characteristics, conversations, and contexts. University of Toronto Press. 
Laurila, K. (2016). Indigenous knowledge? Listening for the drumbeat and searching for how I know. Qualitative Social Work, 15(5-6), 610-618. https://doi. org/10.1177/1473325016652674

Little Bear, L. (2000). Jagged worldviews colliding. In M. Battiste (Ed.), Reclaiming Indigenous voice and vision (pp. 77-85). UBC Press.

Manitowabi, S., \& Gauthier-Frohlick, D. (2012). Relationship building: A best practice model for Aboriginal women's health research. Native Social Work Journal, 8, 57-74.

McGregor, D. Restoule, J. P., \& Johnston, R. (2018). Indigenous Research: Theories, practices, and relationships. Canadian Scholars Press.

McGuire-Adams, T. (2017). Anishinaabeg women's stories of wellbeing: Physical activity, restoring wellbeing, and confronting the settler-colonial deficit analysis. Journal of Indigenous Wellbeing, 2(3), 90-104.

Pedri-Spade, C. (2016). The drum is your document: Decolonizing research through Anishinabe song and story. International Review of Qualitative Research, 9(4), 385-406.

Ray, L. (2016). "Beading becomes a part of your life:” Transforming the academy through the use of beading as a method of inquiry. International Review of Qualitative Research, 9(3), 363-378. https://doi.org/10.1525/irqr.2016.9.3.363

Settee, P. (2013). Pimatisiwin: The good life, global Indigenous knowledge systems. J. Charlton.

Sinclair, R. (2019). Aboriginal social work education in Canada: Decolonizing pedagogy for the seventh generation. First Peoples Child and Family Review, Special Issue celebrating 15 years of wisdom. 14(1), 9-21.

Stonechild, B. (2020). Loss of Indigenous Eden and the fall of spirituality. University of Regina Press.

Talaga, T. \& McMurchy, V. (2019). Bringing Indigenous viewpoints to higher education. In Academic Matters. Ontario Confederation of University Faculty Association's Journal of Higher Education. Decolonizing the university in an era of Truth and Reconciliation. Spring, 3-6.

Truth and Reconciliation Canada. (2015). Honouring the truth, reconciling for the future: Summary of the final report of the truth and reconciliation commission of Canada. Truth and Reconciliation Commission of Canada.

United Nations. (2007). Declaration on the rights of Indigenous peoples. United Nations.

Universities Canada. (2015). Principles for Indigenous Education. https://www.univcan.ca/mediaroom/media-releases/universities-canada-principles-on-indigenous-education/

Van Katwyk, T. \& Case, R. A. (2016). From suspicion and accommodation to structural transformation: Enhanced scholarship through enhanced community-university relations. In Engaged Scholar Journal: Community-Engaged Research, Teaching, and Learning, 2(2), 25-43.

Victor, J., Linds, W., Episkenew, J., Goulet, L., Benjoe, D., Brass, D., Pandey, M., \& Schmidt, K. (2016). Kiskenimisowin (self-knowledge): Co-researching Wellbeing With Canadian First Nations Youth Through Participatory Visual Methods. International Journal of Indigenous Health, 11(1), 262-278. 